\title{
Phenotypic Variation in Leaf Morphology of the USDA, ARS Sweetpotato (Ipomoea batatas) Germplasm Collection
}

\author{
D. Michael Jackson and Howard F. Harrison \\ U.S. Department of Agriculture, Agricultural Research Service, U.S. \\ Vegetable Laboratory, Charleston, SC 29414
}

\author{
Robert L. Jarret \\ U.S. Department of Agriculture, Agricultural Research Service, Plant \\ Genetic Resources Conservation Unit, Griffin, GA 30223
}

\section{Phillip A. Wadl}

U.S. Department of Agriculture, Agricultural Research Service, U.S. Vegetable Laboratory, Charleston, SC 29414

Additional index words. characterization, Convolvulaceae, diversity, phenotyping

\begin{abstract}
During 2012-14, 737 sweetpotato, Ipomoea batatas (L.) Lam. (Convolvulaceae), plant introduction (PI) accessions from the U.S. Department of Agriculture, Agricultural Research Service (USDA, ARS) sweetpotato germplasm collection were evaluated for several phenotypic leaf and plant characteristics, and a photographic record of each accession was made. Data were prepared for placement in the USDA, ARS Germplasm Resources Information Network (GRIN) database and the sweetpotato ontology. The parameters recorded for each genotype were canopy coverage, vine length, general leaf outline, leaf lobing, shape of the central leaf lobe, number of leaf points, leaf petiole length, leaf width, leaf length, leaf width $\times$ length, and leaf width/length (aspect ratio). The data indicate that there is wide genetic diversity for vegetative phenotypic characteristics within the USDA, ARS sweetpotato germplasm collection. This study provides important phenotype information for the USDA, ARS sweetpotato collection that has been lacking and can be used for curation of the collection and by researchers and breeders working with this important global food crop.
\end{abstract}

Sweetpotato, I. batatas (L.) Lam. (Convolvulaceae), is an important food crop, and breeding efforts are necessary to provide new varieties to overcome pest, disease, and climate challenges and to maintain world food production. Fortunately, there is wide genetic

Received for publication 6 Nov. 2019. Accepted for publication 9 Jan. 2020.

Published online 20 February 2020.

We thank Ty Phillips, Sarah Moon, and Merrelyn Spinks for their excellent technical support. This project was partially funded for 2 years by the U.S. Department of Agriculture (USDA), Research, Education, and Economics, Agricultural Research Service, Office of National Programs, Crop Production and Protection as Germplasm Evaluation Project No. 6659-22000-024-00D ("Evaluating the Integrity of the Sweetpotato Germplasm Collection"). Mention of trade names or commercial products in this article is solely for the purpose of providing specific information and does not imply recommendation or endorsement by the USDA; USDA is an equal opportunity provider and employer.

D.M.J. is the corresponding author. E-mail: mike. jackson@usda.gov.

This is an open access article distributed under the CC BY-NC-ND license (https://creativecommons. org/licenses/by-nc-nd/4.0/). and phenotypic diversity within the worldwide sweetpotato and Ipomoea germplasm collections for breeding efforts (Gichuki et al., 2003; Jarret et al., 2019; Khoury et al., 2015; Su et al., 2017). Sweetpotato has high genetic polymorphism and great diversity in morphological traits (Andrade et al., 2017; Su et al., 2016; Wadl et al., 2018). Much of the genetic diversity of sweetpotato is preserved at several germplasm collections throughout the world. Kim et al. (2018) reported more than 20,000 I. batatas accessions in 10 collections from just nine countries, and Roca et al. (2007) reported more than 27,000 sweetpotato accessions from 36 collections in 32 countries. This latter list was updated to include 35,478 sweetpotato accessions held in ex situ gene banks globally (Food and Agriculture Organization, 2010). The most important sweetpotato collection is with the International Potato Center (CIP), Lima, Peru (Huamán and de la Puente, 1988) with more than 5500 accessions of I. batatas listed (CIP, 2019). The U.S. Department of Agriculture, Agricultural Research Service (USDA, ARS) also maintains an important sweetpotato germplasm collection (762 accessions available) at the Plant Genetics Resources Conservation
Unit (PGRCU) in Griffin, GA (USDA, $2019 b, 2019$ c), which is part of the U.S. National Plant Germplasm System.

Although there has been significant progress in describing the genetic diversity of USDA, ARS sweetpotato germplasms (Wadl et al., 2018), phenotyping data has lagged behind (Jackson et al., 2018, 2019a). Morphological descriptors (CIP, 2010; Hualla et al., 2015; Huamán, 1991, 1992) are often used to characterize phenotypes and for making selections in breeding programs (Grüneberg et al., 2015; Wadl et al., 2018). A total of 104 potential descriptors were defined for sweetpotato (Huamán, 1991); however, morphoagronomic characters other than the International Plant Genetic Resources Institute sweetpotato descriptors (Huamán, 1991) also have been used by several researchers (Efisue, 2015; Galal and El Gendy, 2017; Reddy et al., 2018). A modified version of the sweetpotato descriptors is used in the GRIN database (CIP, 2010; USDA, 2019a), and has been adapted for the sweetpotato ontology (Anonymous, 2019a, 2019b; Hualla et al., 2015). In addition, other efforts have been initiated to standardize data collection methods used for germplasm characterization in sweetpotato (Anonymous, 2019c).

Phenotyping of sweetpotatoes has lagged behind the development of new genomic tools for this crop (Kim et al., 2016; Wadl et al., 2018). It is important to link genomic information (genotype) with useful characteristics (phenotype) in a sweetpotato breeding program. For the USDA, ARS sweetpotato germplasm collection, no accession has been phenotyped completely for all descriptor traits, and fewer than $40 \%$ of the collection (300 PIs) have any phenotype data for leaf characteristics (USDA, 2019b, 2019c). The goal of this study was to provide comprehensive phenotype data for plant and leaf descriptors of PIs from the USDA, ARS sweetpotato collection to minimize phenotypic data gaps within the collection.

\section{Materials and Methods}

From 2012 to 2014, in vitro plantlets from 737 sweetpotato accessions were obtained from the PGRCU in glass tissue-culture tubes, which were placed in a tissue-culture room with $16 \mathrm{~h} / \mathrm{d}$ fluorescent lighting and 25 to $30{ }^{\circ} \mathrm{C}$ at the USDA, ARS, U.S. Vegetable Laboratory (USVL) (lat. $32.796^{\circ} \mathrm{N}$, long. $80.061^{\circ} \mathrm{W}$ ). After removal from tissue culture, all MS basal media (Murashige and Skoog, 1962) were rinsed from each plantlet's roots and then it was planted in a $15-\mathrm{cm}$ diameter plastic pot filled with soil (Metro Mix 360; Sun Gro Horticulture, Agawam, MA). After watering, the plantlet and pot were covered with a $15 \mathrm{~cm} \times 15 \mathrm{~cm}$ plastic bag (2-mil clear-line single-track seal, F20606; Elkay Plastics, Commerce, CA) to maintain relative humidity at $\approx 100 \%$. Pots were kept in indirect sunlight for several days until the plantlet had become established, and then they were moved to a greenhouse. At that time, a $2-\mathrm{cm}$ isosceles triangle piece was 
cut off the corner of the plastic bag to increase airflow and reduce the humidity surrounding the plantlets. These holes were enlarged as the plantlets became stronger, until eventually, the plastic bag was removed from the pot when the plantlet became established. During the winter months, plants were maintained in the greenhouse where they were fertilized monthly with Osmocote $15 \mathrm{~N}-9 \mathrm{P}-12 \mathrm{~K}$ plus (Scotts Co. LLC, Marysville, $\mathrm{OH}$ ).

In the spring of each season (2012-14), plants from the greenhouse were transferred to a hilled plant bed on the USVL that was covered with plastic film. The plants were centered $\approx 3.0 \mathrm{~m}$ apart in the plant beds. When these plants had become large enough, rootless cuttings $(\approx 30 \mathrm{~cm}$ long) were taken from them to be planted into the production field.

Field plots were maintained at the USVL for three growing seasons (2012-14) using two adjacent fields. Soil in the two fields was Yonges loamy fine sand (Aeric Paleaquults) (USDA, 2007). This is a poorly drained, nearly level soil with a $\mathrm{pH}$ of 6.0 to 6.4 and less than $1 \%$ organic matter. Fields were prepared by forming narrow beds $\approx 30 \mathrm{~cm}$ tall and $1.0 \mathrm{~m}$ apart. Fertilizer was $1120 \mathrm{~kg} / \mathrm{ha}$ of $4 \mathrm{~N}-8 \mathrm{P}-12 \mathrm{~K}$, incorporated into the soil before bedding. Formed beds were treated with the herbicide clomazone (Command 3ME; FMC Corp., Philadelphia, PA) at $0.4 \mathrm{~kg}$ ai/ha.

Each sweetpotato accession was planted in two replications of single-row, 5-plant plots arranged in a randomized complete block experimental design. Plots were handplanted by laying the rootless cuttings on the soil surface and pushing the cut ends into the ground at least $15 \mathrm{~cm}$ with a planting stick. Cuttings were placed $\approx 30 \mathrm{~cm}$ apart within plots. In 2012, plots were planted side by side, but because of problems that year with more aggressive PIs overrunning plots of slower growing or less vigorous PIs, we staggered plots in 2013 and 2014. In those years, efforts were made to keep PIs from running into other plots by turning the runners back, or in some cases, trimming them. In 2012, 102 accessions were planted on 26 July and 83 accessions were planted on 17 August. In 2013, 380 accessions were planted on 27 June, and in 2014 all 737 accessions were planted on 18 June. Local production practices were followed (Loebenstein and Thottappilly, 2009), except no insecticides were used. Plots were cultivated one time at 6 to 8 weeks posttransplanting, and they were hand-weeded after that. Weather conditions during this study were typical for summers in Charleston County, SC. From the time of planting until the time of leaf sampling, daytime high temperatures ranged from 26 to $36^{\circ} \mathrm{C}(2012), 28$ to $36^{\circ} \mathrm{C}$ (2013), and 31 to $37^{\circ} \mathrm{C}$ (2014); nighttime lows ranged from 18 to $26^{\circ} \mathrm{C}$ (2012), 22 to $25^{\circ} \mathrm{C}$ (2013), and 22 to $27^{\circ} \mathrm{C}(2014)$, and rainfall was $38 \mathrm{~cm}$ (2012), $18 \mathrm{~cm} \mathrm{(2013),} \mathrm{and} 20 \mathrm{~cm}$ (2014). When rainfall was not adequate during the growing season, supplemental overhead irrigation was applied.
Plant characteristics (vine length and canopy coverage) were rated in the field on 30 July to 1 Aug. 2013 (33-35 d after planting) and 27 to 29 July 2014 (39-41 d after planting). Vine lengths were measured as the length of the longest vine using the following scale: $1=<30 \mathrm{~cm}$ (compact), $3=31-80 \mathrm{~cm}$ (semicompact), $5=81-120 \mathrm{~cm}$ (long), $7>$ $120 \mathrm{~cm}$ (very long). Canopy ratings were made on the same dates using the following scale: $1=$ less than $50 \%$ of the ground surface covered within $0.5 \mathrm{~m}$ of the plant, $3=50 \%$ to $70 \%, 5=71 \%$ to $90 \%$, and $7>90 \%$.

Photographs of the foliage of each accession were taken from the plant beds and field plots using a 10.1 mega-pixel digital camera with $\times 3$ optical zoom (Cybershot DSC-N2; Sony Corporation, Tokyo, Japan). Individual plants were photographed in the plant beds on 14 and 30 Aug. 2012, 9 to 21 May, and 5 and 17 June 2013; and 12, 20, and 28 May, 2 to 6, 11 to 12 , and 23 June, and 11 to 17 July 2013. Field plots of individual accessions were photographed on 2, 9, 16, 23, and 30 Aug.; 6, 13 to 14, and 20 Sept.; and 4 and 15 Oct. 2012; and 12, 22 to 25, and 29 to 31 July, and 1 to 2 and 12 to 19 Aug. 2013; and 1, 10 to 11 , 21 to 22 , and 30 to 31 July and 1 Aug. 2014.

Leaf samples were taken 16 to 20 Aug. 2012 (first planting), 6 to 11 Sept. 2012 (second planting), 22 to 29 July 2013, and 21 to 31 July 2014. Three mature leaves were collected from each replication of each accession. Mature, but not senescent, leaves were selected from the central portions of the vines. After the leaves had been brought into the laboratory, the length of the pedicel of each leaf was measured. Then, they were carefully spread on a piece of graph paper $(2.54 \mathrm{~mm} \times 2.54 \mathrm{~mm}$ squares $)$ for a photographic record using the same digital camera used to photograph the field plots. After both the top and bottom of each leaf had been photographed, the photo files were downloaded and a printed copy of each leaf was made. These prints were used later to determine several phenotypic characteristics (Huamán, 1991; slightly modified by Biodiversity International, 2011) from each leaf, including mature leaf size, mature leaf lobing, general leaf outline, number of leaf lobes, shape of the central leaf lobe, number of leaf points (distinct sharp projections), leaf width, and leaf length. The aspect ratio (ratio between length and width of a leaf) and leaf width $\times$ leaf length also were determined.

In the current GRIN database for sweetpotato, there are subjective descriptors for plant type at growth stages 5 to 6 (PLANTTYPE) for 340 accessions, mature leaf lobing at growth stage 7 (MATLFLOBE) for 320 accessions, mature leaf size at growth stage 7 (MATLFSIZE) for 318 accessions, petiole length at growth stages 6 to 7 (PETIOLELEN) for 339 accessions, vine internode length at growth stage 6 (VINEINLEN) for 319 accessions, and vine internode diameter at growth stage 6 (VINEINTDIA) for 339 accessions (USDA, 2019c). Data from the present study were compared with this information in the GRIN database.
Raw data and summary tables for individual sweetpotato PIs from this study are available in the U.S. Public Domain at Ag Data Commons, USDA, ARS, National Agricultural Library (Jackson et al., 2019b). Data also were prepared for entry into the sweetpotato ontology (Anonymous, 2019b; Hualla et al., 2015) using the Crop Ontology Curation Tool (Anonymous, 2019a). The sweetpotato ontology database uses the same descriptors from Huamán (1991) that we used, and it is one of eight species-specific crop ontologies hosted in the Planteome project portal (Cooper et al., 2018). The Planteome database is a centralized online plant informatics portal that provides reference ontologies that describe phenotypes, genotypes, and other useful information about a plant species (Meier et al., 2016).

\section{Results}

Four genotypes were determined to have duplicates in the USDA, ARS collection, so data from only one accession were used. The duplicate accessions were 'Tainung 57' (PI 531147 and PI 573295), 'Wagabolige' (PI 595888 and PI 633966), IITA-TIS 9101 (PI 599385 and PI 606278), and 'Helena' (PI 606268 and PI 612696), with each of the first listed PI accessions used in this study. The leaves of two accessions ['Topaz' (PI 566659) and W-51-19 (PI 634424)] showed severe deformation symptoms from virus infection in pots, plant beds, and the field, so they also were deleted from these analyses, as virus infections are known to affect leaf shape (Moyer and Salazar, 1989). Therefore, data from 731 of the original 737 accessions are reported in this paper.

The USDA, ARS sweetpotato germplasm collection varied widely in vine lengths and canopy coverage of field plots (Table 1). Only $\approx 4 \%$ of the PI accessions had vine lengths less than $30 \mathrm{~cm}$. Nearly $16 \%$ of the accessions had average vine lengths in excess of $120 \mathrm{~cm}$, but no vines were longer than 180 $\mathrm{cm}$. The remaining $80 \%$ of the accessions had vine lengths between 31 and $120 \mathrm{~cm}$. Nearly $17 \%$ of the accessions had leaves that covered more than $90 \%$ of the soil surface, whereas less than $3 \%$ of the accessions had soil surface coverage of less than $50 \%$. The remaining $80 \%$ of the accessions had canopy coverage ratings between $50 \%$ and $90 \%$. There were no significant correlations $(5 \%$ level) between canopy coverage and vine length $\left(\mathrm{y}=-0.0698 \mathrm{x}+4.9563, R^{2}=0.0045\right.$, $\mathrm{N}=622, P=0.0921)$ or between canopy coverage and leaf length/width $(\mathrm{y}=-0.0494 \mathrm{x}$ $\left.+5.8819, R^{2}=5 \mathrm{E}^{-06}, \mathrm{~N}=633, P=0.9559\right)$. However, canopy coverage was significantly, although weakly, correlated with leaf width $\left(\mathrm{y}=0.2499 \mathrm{x}+2.3383, R^{2}=0.0737, \mathrm{~N}=633\right.$, $P<0.00001)$, leaf length (y $=0.3931 \mathrm{x}+$ $\left.0.4232, R^{2}=0.1269, \mathrm{~N}=633, P<0.00001\right)$, and leaf length $\times$ width $(\mathrm{y}=0.0064 \mathrm{x}+4.5576$, $\left.R^{2}=0.0277, \mathrm{~N}=633, P<0.00001\right)$. All accessions with average canopy coverage ratings of 1 or 2 had a length $\times$ width of less than $250 \mathrm{~cm}^{2}$ (range $40.1-432.0 \mathrm{~cm}^{2}$ ) (Figs. 1 and 2). 
Table 1. Distribution of values for average ratings of canopy coverage and length of the longest vine for sweetpotato PI accessions grown in 2013 and 2014 field plots at Charleston, SC.

\begin{tabular}{llrr}
\hline Mean rating & \multicolumn{1}{c}{ Descriptor value } & Number of PIs & Percentage of PIs \\
\hline Canopy coverage & & & \\
$\quad$ rating $(1,3,5,7)$ & & 17 & 2.7 \\
1 & $<50 \%$ soil surface shaded & 254 & 40.5 \\
3 & $50 \%$ to $70 \%$ soil surface shaded & 250 & 39.9 \\
5 & $70 \%$ to $90 \%$ soil surface shaded & 106 & 16.9 \\
7 & $>90 \%$ soil surface shaded & 627 & 100 \\
Total & & & \\
& & & \\
Vine length & & 27 & 3.7 \\
rating $(1,3,5,7)$ & $<30 \mathrm{~cm}$ & 279 & 38.5 \\
1 & $31-80 \mathrm{~cm}$ & 305 & 42.0 \\
3 & $81-120 \mathrm{~cm}$ & 115 & 15.8 \\
5 & $>120 \mathrm{~cm}$ & 726 & 100 \\
7 & & & \\
Total & & & \\
\hline
\end{tabular}
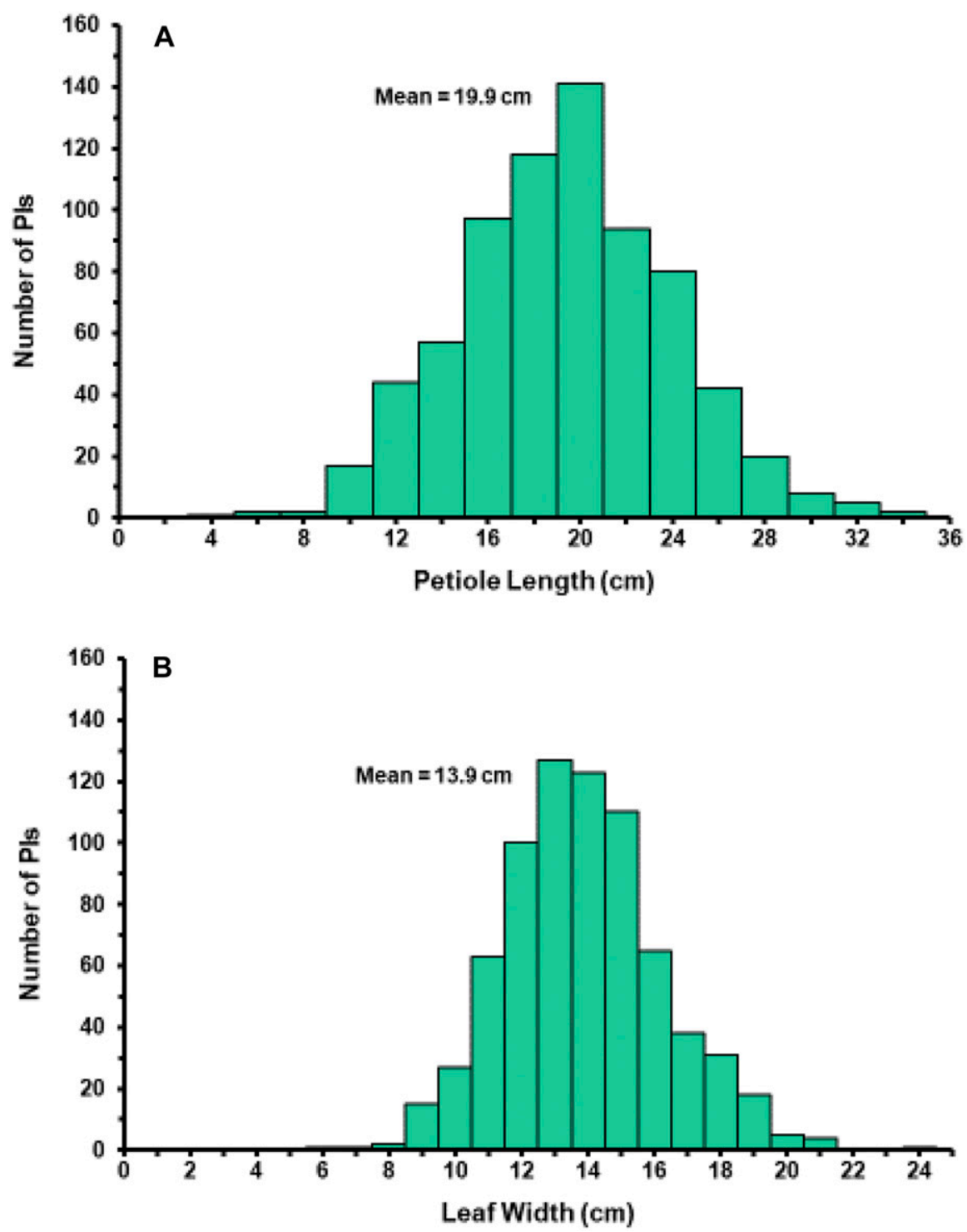

Fig. 1. Frequency distribution of average petiole lengths $(\mathbf{A})$ and leaf widths $(\mathbf{B})$ for green mature leaves of 731 sweetpotato PIs grown in field plots at Charleston, SC, in 2012-14.

The average length of sweetpotato leaf petioles in this study ranged from 5.0 to 34.3 $\mathrm{cm}(\bar{x}=19.9 \mathrm{~cm})$, which is similar to the 5 - to 30 -cm length reported by Woolfe (1992). The distribution of petiole lengths followed a normal distribution (bell-shaped curve) (Fig. 1). The GRIN database for sweetpotato (USDA, 2019c) currently lists leaf petiole lengths (PETIOLELEN) for 339 PIs (Table 2). In that database, there is a higher percentage of PIs with short $(10-15 \mathrm{~cm})$ or very short $(<10 \mathrm{~cm})$ petioles $(34.6 \%)$ than we found in the current study $(13.9 \%)$. In addition, there is a higher percentage of PIs with very long $(>25 \mathrm{~cm})$ petioles $(20.7 \%)$ in the GRIN database than we observed (13.0\%). Furthermore, there was only a weak correlation between the subjective values in the GRIN database $(1,3,5,7,9)$ for PETIOLELEN and our petiole measurements for the same 299 PIs $\left(\mathrm{y}=0.3767 \mathrm{x}+17.391, R^{2}=\right.$ $0.0473, \mathrm{~N}=299, P=0.00015$ ). We observed that leaf petioles continue to grow until the leaf reaches maturity; so, it is important to measure this characteristic on fully mature leaves. In the current study, we sampled leaves over a short time interval on fully expanded leaves. However, the age of leaves in the GRIN database for sweetpotato were not reported, which could contribute to the observed differences in the distribution of petiole lengths between our study and what is reported in the GRIN database (Table 2).

The distributions of mature leaf size (MATLFSIZE) categories were similar between this study and for data reported in the GRIN database for sweetpotato with more than three-fourths of the PI being categorized as having medium-sized leaves (Table 2). However, we found very few accessions (5) with small leaves $(<8 \mathrm{~cm})$. Interestingly, 14 accessions with small leaves were reported from the GRIN database, even though all of these same accessions were included in our study, suggesting that perhaps some of the data from the GRIN database were collected from leaves that were not fully mature. In the present study, leaves ranged in width from 5.7 to $21.5 \mathrm{~cm}(\bar{x}=13.9 \mathrm{~cm})$, and they ranged in length (longest dimension) from 7.0 to $21.8 \mathrm{~cm}(\bar{x}=13.7 \mathrm{~cm})$ (Figs. 1 and 2). For a few of the accessions (49 PIs), the longest dimension was to the base of the leaf petiole; however, for most accessions (682 PIs), the longest dimension was to the bottom edge of the leaf lamina at a lobe extending below the base of the petiole. Examples of each can be seen in Figs. 3 and 4.

The computed parameter of leaf length $x$ leaf width ranged from 40.1 to $432 \mathrm{~cm}^{2}$ and averaged $194.7 \mathrm{~cm}^{2}$ (Fig. 2). Because of the irregular shapes of the leaves, this is not a true measure of leaf area, but it illustrates the wide variation in leaf sizes among the USDA, ARS sweetpotato germplasm collection. The largest leaves in this study were for PI 585071 ('Won-Mi'), PI 634513 ('CN 1421-68'), PI 564134 ('L 13'), and PI 564135 ('L 18') that had length $\times$ width $(\mathrm{L} \times \mathrm{W})$ values more than $400 \mathrm{~cm}^{2}$, whereas four accessions had $\mathrm{L} \times \mathrm{W}$ values of less than $70 \mathrm{~cm}^{2}$. The aspect ratio of leaf lengths (longest dimension) to leaf width $(\mathrm{L} / \mathrm{W})$ ranged from 0.75 to 1.55 and averaged 1.00 (Fig. 2). Approximately half (52.4\%) of the accessions (383 PIs) had leaves wider than long and $47.6 \%$ (348 PIs) had leaves longer than wide.

Several leaf morphology parameters (Biodiversity International, 2011; Huamán, 1991; USDA, 2019c) were recorded for each leaf. We used the general leaf outline 

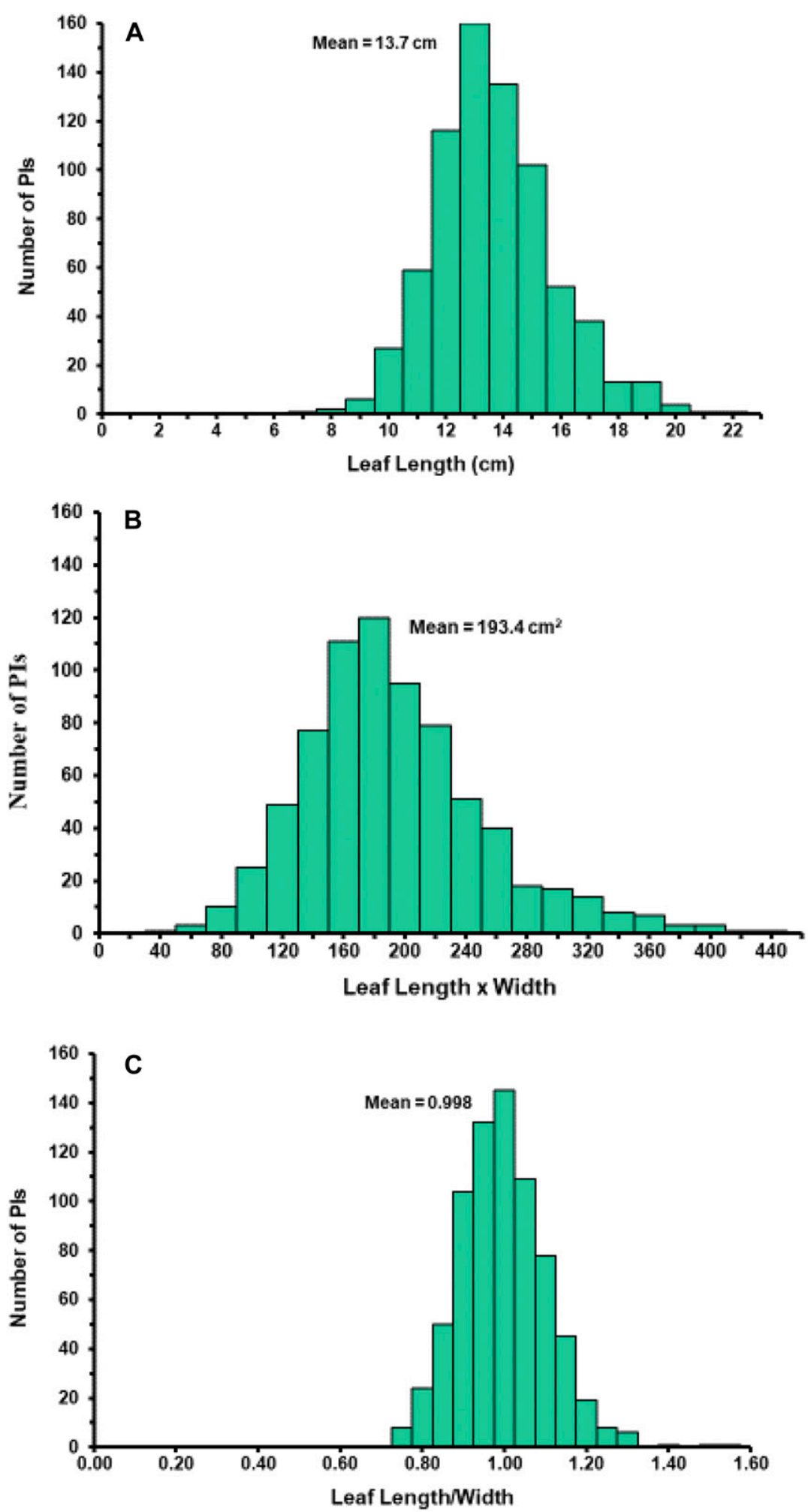

Fig. 2. Frequency distribution of average leaf lengths (A), leaf width $\times$ leaf lengths (longest dimension) (B), and leaf length (longest dimension)/leaf width (aspect ratio) (C) for green mature leaves of 731 sweetpotato PIs grown in field plots at Charleston, SC, in 2012-14.

categories listed by Huamán (1991): almost divided, cordate (heart-shaped), hastate, lobed, reniform (kidney-shaped), rounded, and triangular (Table 3, Fig. 3). Other recognized leaf shapes are auriculate, deltoid, elliptical, lanceolate, linear, oblong, oblanceolate, ovate, and spatulate (Anonymous, 2019a, 2019b). General leaf outline presently is not a descriptor in the GRIN database for sweetpotato (USDA, 2019a), but this descriptor is included in the sweetpotato ontology (Anonymous, 2019a). The largest subjectively rated categories for general leaf outline were for lobed $(47.3 \%)$, cordate $(32.3 \%)$, and triangular (8.9\%) leaves (Table 3$)$.

The distribution of mature leaf lobing (MATLFLOBE) categories varied somewhat between our study and the GRIN database for sweetpotato (Table 2), but because these categorizations are subjective, some variation in scoring is to be expected. Also, only 320 accessions were included in the GRIN database compared with 731 in our study. In the present study, leaves had from 1 to 9 leaf lobes (Table 3 ). There were nearly equal numbers of accessions with toothed $(22.2 \%)$, triangular $(22.0 \%)$, and semielliptic $(22.0 \%)$ central leaf lobes, with fewer numbers with semicircular $(14.8 \%)$, elliptic $(11.5 \%)$, and lanceolate $(5.9 \%)$ central leaf lobes (Table 3 ). Leaves had from 0 to 12 distinct leaf points, with 3 points $(18.9 \%), 4$ points $(17.9 \%)$, and 5 points $(24.1 \%)$ being the most common categories (Table 3, Fig. 4).

\section{Discussion}

The value of any germplasm collection is increased when that material has been characterized, evaluated, and properly documented for useable agronomic traits (Araus and Cairns, 2014; Grüneberg et al., 2015; Jarret et al., 2019). It is important that genetic resources are well characterized and readily available for use in breeding programs for developing varieties with improved agronomic and culinary traits and with resistance to diseases, pests, and environmental stresses. Unfortunately, much of the genetic material in the USDA, ARS sweetpotato collection lacks full characterization (Jackson et al., 2018, 2019a; Jarret et al., 2019; USDA, 2019a, 2019b). Although plant and leaf morphological characteristics have been used as descriptors for sweetpotato germplasm collections for several years (Huamán, 1988, 1991), fewer than half of the accessions in the USDA, ARS collection have descriptor data listed in the GRIN Global database for sweetpotato (USDA, $2019 \mathrm{~b}$ ). The present study adds plant and leaf descriptor data for most of the unique sweetpotato accessions (733 PIs) in this collection. These morphological data are important for identification and categorization of new or existing clones, for the identification of duplicate accessions in sweetpotato germplasm collections, for determining relative relationships among accessions, for establishment of core collections, and for selecting parental materials in breeding programs (Huamán, 1992). The raw data from this study have been made publically available (Jackson et al., $2019 \mathrm{~b}$ ), and in the present article, we have summarized and interpreted this information.

A list of sweetpotato descriptors was first developed at a workshop during an ad hoc working group meeting of the International Board of Plant Genetic Resources (IBPGR) in 1980 (Huamán, 1988). A modified version of the sweetpotato descriptors (Huamán, 1991) is used in the GRIN database (CIP, 2010; USDA, 2019a), and has been adopted for the sweetpotato ontology (Hualla et al., 2015). These morphological descriptors (Huamán, 1991) have been used in many studies throughout the world to characterize sweetpotato leaf traits (Amoatey et al., 2016; 
Table 2. Distribution of values for the descriptors leaf petiole length (PETIOLELEN), mature leaf size (MATLFSIZE), and mature leaf lobing (MATLFLOBE) for this study and as reported in the GRIN database for sweetpotato (USDA, 2019a).

\begin{tabular}{|c|c|c|c|c|c|}
\hline GRIN code & GRIN descriptor & $\begin{array}{l}\text { Number of PIs } \\
\text { (this study) }\end{array}$ & $\begin{array}{l}\text { Percentage of PIs } \\
\text { (this study) }\end{array}$ & $\begin{array}{l}\text { Number of PIs } \\
\text { (GRIN data) }\end{array}$ & $\begin{array}{c}\text { Percentage of PIs } \\
\text { (GRIN data) }\end{array}$ \\
\hline 1 & Very short $(<10 \mathrm{~cm})$ & 7 & 1.0 & 27 & 8.0 \\
\hline 5 & Intermediate $(16-20 \mathrm{~cm})$ & 279 & 38.1 & 91 & 26.8 \\
\hline 7 & Long $(21-25 \mathrm{~cm})$ & 256 & 35.0 & 61 & 18.0 \\
\hline 9 & Very long $(>25 \mathrm{~cm})$ & 95 & 13.0 & 70 & 20.7 \\
\hline \multicolumn{6}{|c|}{$\begin{array}{l}\text { Mature leaf size } \\
\text { (MATLFSIZE) }\end{array}$} \\
\hline 3 & Small $(<8 \mathrm{~cm})$ & 5 & 0.7 & 14 & 4.4 \\
\hline 5 & Medium $(8-15 \mathrm{~cm})$ & 564 & 77.2 & 251 & 78.9 \\
\hline 7 & Large $(16-25 \mathrm{~cm})$ & 162 & 22.1 & 53 & 16.7 \\
\hline Total & & 731 & 100 & 318 & 100 \\
\hline 4 & Slight to moderate & 55 & 7.5 & 20 & 6.3 \\
\hline 5 & Moderate & 80 & 10.9 & 55 & 17.2 \\
\hline 6 & Moderate to deep & 48 & 6.6 & 11 & 3.4 \\
\hline 7 & Deep & 64 & 8.8 & 33 & 10.3 \\
\hline 9 & Very deep & 19 & 2.6 & 13 & 4.1 \\
\hline Total & & 731 & 100 & 320 & 100 \\
\hline
\end{tabular}

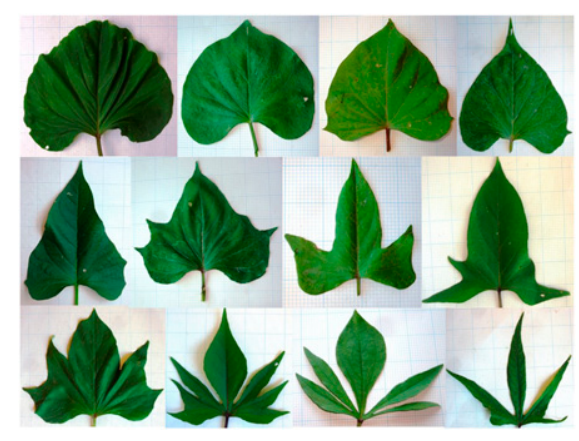

Fig. 3. Representative leaves showing the classifications for the general leaf outline (Huamán, 1991) for 12 sweetpotato PIs grown in field plots at Charleston, SC, in 2012-14. Top row (left to right): rounded, 'TIS 83/176' (PI606260); reniform, 'Allgold' (PI566610); cordate, 'Gem' (PI508528); cordate, 'Pepa de Oro' (PI538352); middle row (left to right): triangular, '4A-6' (PI629275); triangular, 'Xushu 18' (PI595873); hastate, 'Kumara Enua' (PI344140); hastate, '168' (PI531114); bottom row (left to right): lobed, 'IITA-TIS 3290' (PI595883); lobed, 'IAC-72 Eucaru' (PI538288); almost divided, 'AVRDC-CN 1732-4' (PI633964); and almost divided, 'Morado de Calango T-1' (PI538302).

Andrade et al., 2017; Bhattarai et al., 2017; Chipungu et al., 2017; Elameen et al., 2011; Fongod et al., 2012; Gupta et al., 2018, 2019; Hue et al., 2012; Manifesto et al., 2010; Maquia et al., 2013; Neiva et al., 2011; Palumbo et al., 2019; Placide et al., 2015; Shumbusha et al., 2017; Su et al., 2016; Tairo et al., 2008; Veasey et al., 2007; Vimala et al., 2012). For example, Elameen et al. (2011) measured plant type, general leaf outline, type of leaf lobes, number of leaf lobes, shape of the central leaf lobe, and mature leaf size.
However, other researchers (Afuape et al., 2011; Aguoru et al., 2015; Alves et al., 2017; Batcho et al., 2018; Daros et al., 2002; Nwankwo et al., 2012; Reddy et al., 2018) used morpho-agronomic characters that differed from the IBPGR sweetpotato descriptors. For example, Reddy et al. (2018) characterized 15 sweetpotato cultivars for vine length and number of leaves and shoots per plant. Hue et al. (2012) measured maximum leaf width and length, leaf arrangement, venation, and other qualities of the leaves for six different local sweetpotato cultivars in Malaysia. The leaf character data from the present study are consistent with the published results from many of the morphological studies from other countries.

Most sweetpotato accessions have leaves that are glabrous and green, but some genotypes have yellowish or purple leaves, especially late in the season (Jackson et al., 2019a; Woolfe, 1992). All sweetpotato leaves are simple, have palmate venation, and have distinct petioles with alternating attachments arranged spirally on the stem (Woolfe, 1992). Although most sweetpotato cultivars cannot climb, there are a small number of twining genotypes (Martin, 1984). Although the leaves of the sweetpotato accessions in the present study adhered to this general pattern, they varied widely in shape and size, which reflects the wide diversity within this germplasm collection (Jackson et al., 2019b; Jarret et al., 2019). The diversity in sweetpotato has been assessed using morphological, physiological (chemical), and molecular methods (Elameen et al., 2011; He et al., 2006; Huang and Sun, 2000; Luo et al., 2008; Rosero et al., 2019; Wadl et al., 2018; Yada et al., 2010).
Although morphological characterization was the initial method for assessing diversity in sweetpotato (Mohan et al., 2012; Mwanga et al., 2017), morphological characters cannot be used alone to characterize sweetpotato germplasm fully, as "phenotypic diversity is discordant to molecular diversity and both types of data are necessary in order to characterize sweetpotato germplasm" (Elameen et al., 2011). Thus, diversity analyses often include both morphological and molecular information (Alfred et al., 2019; Koussao et al., 2014; Yada et al., 2017). Furthermore, Rosero et al. (2019) found that the inclusion of morphometric (e.g., circularity, aspect ratio, roundness, solidity, area) and colorimetric (CIE $L * a * b * C * h *$ or RGB data from images) information to standard morphological characterization improved estimates of phenotypic plant diversity in sweetpotato, and they were able to discriminate different phenotypes not detected by conventional morphological descriptors. It should be noted that the genetic diversity and population structure (Wadl et al., 2018) and leaf colorimetric data (Jackson et al., 2019a, 2019b) from sweetpotato accessions in the present study were recently published.

There have been many recent studies on the genetic diversity of sweetpotato collection around the world, including Africa (Elameen et al., 2008; Kagimbo et al., 2018; Ngailo et al., 2016; Selaocoe et al., 2019; Tumwegamire et al., 2011; Zawedde et al., 2015), Asia (Fajardo et al., 2002; He et al., 2006; Luo et al., 2016; Rahajeng and Rahayuningsih, 2017; Soegianto et al., 2011; Su et al., 2017; Zhang et al., 2014), Europe (Palumbo et al., 2019; Pipan et al., 2017), South America (da Silva et al., 2013; Veasey 


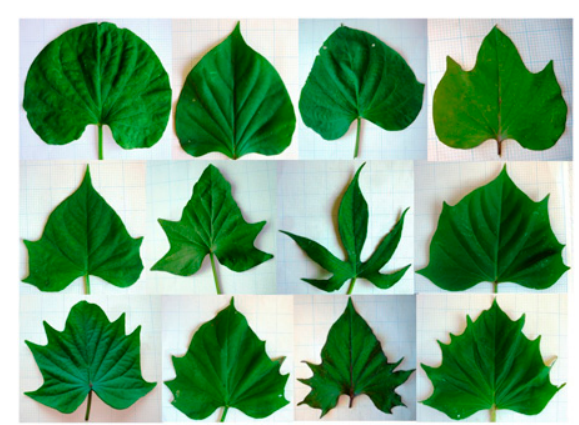

Fig. 4. Representative leaves showing the number of "leaf points" for 12 sweetpotato PIs grown in field plots at Charleston, SC, in 2012-14. Top row (left to right): 0 leaf points, ' $\mathrm{NC} 1327$ ' (PI634392); 1 leaf point, 'CN 1028-15' (PI538284); 2 leaf points, 'W-250’ (PI634457); 3 leaf points, 'B-6369' (PI208886); middle row: 4 leaf points, '11' (PI564097); 5 leaf points, 'Carolina Bunch' (PI634451); 5 leaf points, 'MD 9-35' (PI634464); 6 leaf points, '83003-13', (PI585052); bottom row: 7 leaf points, 'MD 16-109' (PI634468); 8 leaf points, 'MD 807' (PI634478); 9 leaf points, 'Camote Morado' (PI399163); and 10 leaf points, 'Camote Morado-1' (PI531131)

et al., 2008; Zhang et al., 2000), and North America (Jarret and Austin, 1994; Rodriguez-Bonilla et al., 2014; Wadl et al., 2018). From these studies, it has been generally accepted that there is an abundance of genetic diversity in sweetpotato germplasm collections worldwide (Gichuki et al., 2003; Grüneberg et al., 2015; Su et al., 2017; Wadl et al., 2018; Yang et al., 2015); however, smaller geographic collections may show a narrower range of genetic diversity due to inbreeding or other factors (Elameen et al., 2008; Hao et al., 2007; Meng et al., 2018). Within the USDA, ARS sweetpotato collections, there are multiple gene pools and clustering of accessions into geographical groups (Su et al., 2017; Wadl et al., 2018). However, the wide variation of leaf characters shown in this study attests to the extensive genetic diversity of the USDA, ARS sweetpotato germplasm collection (Wadl et al., 2018).

In addition to use in genetic diversity studies, morphological characterization has been used for cultivar identification and for correlation with characteristics of agronomic importance (Karuri et al., 2010; Nwankwo et al., 2012; Rahman et al., 2015; Tairo et al., 2008); however, because morphological characterization is environmentally dependent, it can be unreliable in cultivar identification and classification (Efisue, 2015). Quantitative phenotypic traits result from complex interactions between genetic factors and the environmental conditions, which affect phenotypic expression (Delazari et al., 2018; Manrique and Hermann, 2001; Ochieng, 2019). Like all plant species, sweetpotatoes produce slightly different phenotypes under different environmental conditions (Glato et al., 2017; Sulistiani et al., 2018). This phenotypic plasticity (Sultan, 2000) can manifest itself in different ways, including affecting leaf shape and size.
For example, Sulistiani et al. (2018) reported that sweetpotatoes grown at low altitudes were more twisted and had larger leaves than those grown at high altitudes. Likewise, Irwan et al. (2019) described differences in morphological characteristics of leaves and stems of sweetpotatoes grown in highland or lowland areas of Indonesia. Leaf size, leaf color, general leaf outline, leaf lobing, and other descriptors were different at the highland and lowland sites for the same genotype. Conversely, Gupta et al. (2019) concluded that sweetpotato leaf shape traits, such as circularity and aspect ratio, are largely under genetic control and are not strongly influenced by the environmental conditions. Vimala and Nair (1988) observed that for 20 sweetpotato cultivars, the segregation patterns of several morphological characters showed continuous and overlapping variation, indicating the quantitative nature for the morphological traits they studied. Many of the genotype $\times$ environment interactions for storage root characteristics and yield have been studied in sweetpotato, but little is known concerning environmental effects on leaf characteristics (Grüneberg et al., 2005; Laurie and Booyse, 2015; Mwololo et al., 2009; Ngailo et al., 2019).

There also is variation in leaf characteristics within sweetpotato genotypes, some of which may be genetically controlled (Gupta et al., 2019). For example, from the present study, some accessions had variable numbers of leaf lobes and leaf points even though they were sampled at the same time and there was little difference between plots within the same field. In addition, as with any morphometric character, stem lengths, leaf widths, and leaf lengths varied within genotypes and had different variances (Jackson et al., 2019b). Therefore, it is important when reporting phenotyping data that the location and environmental conditions are specified, as is done in the present study.

Most sweetpotato breeding programs have concentrated on developing improved storage root quality and yield, and little attention has been paid to improving foliage characteristics (Grüneberg et al., 2015; Islam, 2006). However, sweetpotato leaves and stems are commonly used for human consumption or livestock feed in many parts of the world, and the nutritional content of these plant parts is important (Johnson and Pace, 2010; Murugan et al., 2012). Phenotypic leaf characteristics are important in the development of so-called "dual-purpose" sweetpotatoes (food and fodder) (Shumbusha et al., 2017), and leaves and stems are sometimes ensiled or dried for long-term storage and the vegetation structure affects drying times and fermentation characteristics of these materials (An and Lindberg, 2004; Dom et al., 2017). For example, leaf morphology affects drier airflow through aerial vine components (Korese and Hensel, 2016), which can affect quality factors of leaf fodder (Sugiura and Watanabe, 2011).

Leaf morphology and color are also important to the development of ornamental sweetpotato cultivars (Carey et al., 2012). New ornamental cultivars include those with compact and mounding growth characteristics, such as 'Margie Compact' (Anonymous, 2019d), 'IP059' (Meszaros, 2007), the Sweet Caroline Series from North Carolina State University (Pecota et al., 2004a, 2004b, 2004c; Yencho and Pecota, 2008; Yencho et al., 2008), and varieties developed from them (Jandrew, 2008, 2010a, 2010b; Talmadge, 2011). There are even some new twining ornamental cultivars, such as SolarTower ${ }^{\mathrm{TM}}$ Black, that can climb a trellis (Anonymous, 2019e; Winslow, 2018).

Plant and leaf morphology affects canopy coverage, which can affect weed interference, soil erosion, soil moisture loss, and photosynthetic activity (Cavalcante et al., 2018; Harrison and Jackson, 2011; Labonte et al., 1999). Commercial sweetpotatoes are most susceptible to weed competition early in the season when weed interference can dramatically affect yields (Cavalcante et al., 2018; Meyers et al., 2010; Seem et al., 2003; Semidey et al., 1987). However, once the leaf canopy has closed, most sweetpotato cultivars do an excellent job preventing soil erosion and suppressing weed growth through shading and allelopathy (Cavalcante et al., 2018; Seem et al., 2003; Walker et al., 1989). As such, sweetpotatoes have shown potential for controlling invasive plant species when used as a suppressive groundcover (Shen et al., 2015, 2019). Although canopy coverage in sweetpotatoes typically approaches $100 \%$ well before harvest (Labonte et al., 1999), there are differences among genotypes in how long this takes, suggesting that sweetpotato clones may vary substantially in the weed-free interval required to produce maximum yields. Plant growth characteristics, canopy architecture, and leaf morphology all affect groundcoverage. Early-season groundcoverage can help alleviate weed problems (Harrison and Jackson, 2011), but some leading U.S. cultivars, such as Beauregard (PI 566613 in the present study), have spreading genotypes (Huamán, 1991) that do not form a dense leaf canopy very quickly. Although the spreading genotypes grow more rapidly in terms of spreading outward, much of the soil between vines is left bare during early growth and weeds can emerge through the open canopy. These cultivars may be highly susceptible to weed interference to the extent that total crop failures have been reported under high weed populations (Meyers et al., 2010; Seem et al., 2003). Other cultivars have more tolerance to weed interference due to their leaf morphology and vine growth habits (Harrison and Jackson, 2011; Labonte et al., 1999). In a study to determine the effect of vine morphology on weed interference, Labonte et al. (1999) showed that yields of one clone, W241 (subsequently named 'Carolina Bunch', PI 634451 in the present study), were reduced by less than $20 \%$ by weed interference in comparison with weed-free plots, whereas all other clones in the study were reduced by between 50\% and 70\%. 'Carolina Bunch' possesses a vine growth habit that is described 
Table 3. Distribution of values for the descriptors of general leaf outline, shape of the central leaf lobe, leaf lobe number (Huamán, 1991), and number of leaf points for 731 sweetpotato PIs grown in the field at Charleston, SC, 2013 and 2014.

\begin{tabular}{|c|c|c|c|}
\hline Code & Descriptor & Number of PIs & Percentage of PIs \\
\hline \multicolumn{4}{|c|}{ General leaf outline } \\
\hline 1 & Rounded & 1 & 0.1 \\
\hline 2 & Reniform (kidney-shaped) & 30 & 4.1 \\
\hline 3 & Cordate (heart-shaped) & 236 & 32.3 \\
\hline 4 & Triangular & 65 & 8.9 \\
\hline 5 & Hastate & 25 & 3.4 \\
\hline 6 & Lobed & 346 & 47.3 \\
\hline 7 & Almost divided & 28 & 3.8 \\
\hline Total & & 731 & 100 \\
\hline \multicolumn{4}{|c|}{ Shape of central lobe } \\
\hline 0 & Absent & 2 & 0.3 \\
\hline 1 & Toothed & 162 & 22.2 \\
\hline 2 & Triangular & 161 & 22.0 \\
\hline 3 & Semicircular & 108 & 14.8 \\
\hline 4 & Semielliptic & 161 & 22.0 \\
\hline 5 & Elliptic & 84 & 11.5 \\
\hline 6 & Lanceolate & 43 & 5.9 \\
\hline 7 & Oblanceolate & 7 & 1.0 \\
\hline 8 & Linear (broad) & 0 & 0.0 \\
\hline 9 & Linear (narrow) & 3 & 0.4 \\
\hline Total & & 731 & 100 \\
\hline \multicolumn{4}{|c|}{ Number of leaf lobes } \\
\hline 1 & 1 lobe & 208 & 28.5 \\
\hline 2 & 2 lobes & 101 & 13.8 \\
\hline 3 & 3 lobes & 139 & 19.0 \\
\hline 4 & 4 lobes & 100 & 13.7 \\
\hline 5 & 5 lobes & 133 & 18.2 \\
\hline 6 & 6 lobes & 35 & 4.8 \\
\hline 7 & 7 lobes & 12 & 1.6 \\
\hline 8 & 8 lobes & 2 & 0.3 \\
\hline 9 & 9 lobes & 1 & 0.1 \\
\hline Total & & 731 & 100 \\
\hline \multicolumn{4}{|c|}{ Number of leaf points } \\
\hline 0 & 0 points & 1 & 0.1 \\
\hline 1 & 1 point & 58 & 7.9 \\
\hline 2 & 2 points & 80 & 10.9 \\
\hline 3 & 3 points & 138 & 18.9 \\
\hline 4 & 4 points & 131 & 17.9 \\
\hline 5 & 5 points & 176 & 24.1 \\
\hline 6 & 6 points & 93 & 12.7 \\
\hline 7 & 7 points & 36 & 4.9 \\
\hline 8 & 8 points & 12 & 1.6 \\
\hline 9 & 9 points & 3 & 0.4 \\
\hline 10 & 10 points & 1 & 0.1 \\
\hline 11 & 11 points & 1 & 0.1 \\
\hline 12 & 12 points & 1 & 0.1 \\
\hline Total & & 731 & 100 \\
\hline
\end{tabular}

as semierect in a list of vine growth descriptors developed by CIP (Huamán, 1991). In this system, vine morphology is classified as erect, semierect, spreading, and extremely spreading, which are determined by maximum main vine lengths of $<75,75-150,151-250$, and $>250 \mathrm{~cm}$, respectively (Huamán, 1991). Sweetpotatoes with upright growth habit (erect and semierect) have shorter internodes and greater branching, which results in a denser canopy with greater height in the early growth stages in comparison with the spreading-type canopy of long-vined cultivars (Labonte et al., 1999). The superior weed suppression observed with this morphology may result from the more effective shading provided by the canopy as it expands (Harrison and Jackson, 2011). In the GRIN database for sweetpotato, 340 accessions are categorized as compact, semicompact, spread-
Mixing, mislabeling, misidentification, or other errors can occur in the maintenance of sweetpotato germplasm collections, but the extent of errors within the global sweetpotato collections is not known (Jarret et al., 2019). One common problem in sweetpotato germplasm collections is the presence of duplicate accessions that may or may not be labeled the same (Huamán, 1992; Jackson et al., 2018, 2019a). Because most sweetpotato collections are kept in vitro, genetic fingerprinting would be an important tool for maintaining clonal identity. However, phenotypic characterization of plants grown in the field or greenhouse is also necessary to validate the identification of a sweetpotato accession. As such, the CIP sweetpotato germplasm collection has been fingerprinted using a diverse panel of microsatellite markers in conjunction with morphological validation using 30 descriptors (Jarret et al., 2019). Similar efforts are under way for the USDA, ARS collection. This study provides important phenotype information for the USDA, ARS sweetpotato collection that has been lacking and can be used for curation of the collection and by researchers and breeders working with this important global crop.

\section{Literature Cited}

Afuape, S.O., P.I. Okocha, and D. Njoku. 2011. Multivariate assessment of the agromorphological variability and yield components among sweetpotato [Ipomoea batatas (L.) Lam] landraces. Afr. J. Plant Sci. 5:123-132. <https://pdfs. semanticscholar.org/77d5/b143951758bed0 df6e57073c050726787725.pdf>.

Aguoru, C.U., P. Uhia, and J.O. Olasan. 2015 Varietal characterisation and taxonomic evaluation of sweet potato (Ipomoea batatas) using macro- and micromorphological evidence. Open Access Library J. 2:e1757.

Alfred, U.J., C.C. Iheukumere, C.U. Aguoru, O.J. Olasan, and U.M. Sesugh. 2019. Diversity analysis of sweet potato [Ipomoea batatas (L.) Lam] accessions from north central Nigeria using morphological and simple sequence repeats markers. Asian J. Biotechnol. Genet. Eng. 2:115. <http://www.journalajbge.com/index.php/ AJBGE/article/view/30055/56395>.

Alves, R.P., A.F. Blank, A.M.S. Oliveira, A.D.D. Santana, V.S. Pinto, and T.M. Andrade. 2017. Morpho-agronomic characterization of sweet potato germplasm. Hort. Bras. 35:534-541.

Amoatey, H.M., F.L. Sossah, J.K. Ahiakpa, E.K. Quartey, A.S. Appiah, and M.M. Segbefia. 2016. Phenotypic profiles of different accessions of sweet potato (Ipomoea batatas L. Lam) in the coastal savanna agro-ecological zone of Ghana. Afr. J. Agr. Res. 11:2316-2328.

An, L.V. and J.E. Lindberg. 2004. Ensiling of sweet potato leaves [Ipomoea batatas L. (Lam.)] and the nutritive value of sweet potato leaf silage for growing pigs. Asian-Aus J. Anim. Sci. 17:497-503.

Andrade, E.K.V., V. Carvalho de Andrade Júnior, M. Luiz de Laia, J.S. Cunha Fernandes, A.J.M. Oliveira, and A.M. Azevedo. 2017. Genetic dissimilarity among sweet potato genotypes using morphological and molecular descriptors. Acta Sci. Agron. 39:447-455.

Anonymous. 2019a. Sweet Potato Ontology. Crop Ontology Curation Tool. <http://www.cropontol ogy.org/ontology/CO_331/Sweet\%20Potato>.

Anonymous. 2019b. Sweet Potato Ontology. IBC Agroportal LIRMM. <http://agroportal.lirmm.fr/ ontologies/CO_331>. 
Anonymous. 2019c. SweetPotatoBase, Lukas Mueller, contact. GT4SP Project News. <https://www.sweet potatobase.org/>.

Anonymous. 2019d. Ipomoea batatas 'Margie Compact' sweet potato vine. Sedan Floral, Inc. $<\mathrm{http} / /$ www.sedanfloral.com/Plant-Name/Ipomoeabatatas-Margie-Compact $>$.

Anonymous. 2019e. SolarTower ${ }^{\mathrm{TM}}$ Black Ipomoea. Ball Seed, Ball Hort. Co., West Chicago, IL. $<$ https://www.ballseed.com/PlantInfo/?phid=060 208159000573>

Araus, J.L. and J.E. Cairns. 2014. Field highthroughput phenotyping: The new crop breeding frontier. Trends Plant Sci. 19:52-61.

Batcho, A., J.O. Nwogwugwu, S.O. Adeyinka, A. Mohsin, and S. Murtaza. 2018. Evaluation of the agronomic characteristics of 16 varieties of sweet potato (Ipomoea batatas) grown in the agro-ecological conditions of southern Benin. J. Agric. Sci. 9:20-28.

Bhattarai, P., B.M. Sakha, and M. Bhattarai. 2017. Collection and morphological characterization of sweet potato genotypes in Nepal. Nepal. J. Agr. Sci. 15:146-159.

Biodiversity International. 2011. Key access and utilization descriptors for sweet potato genetic resources, p. 524-533. In: A. Alercia (ed.). Key characterization and evaluation descriptors: Methodologies for the assessment of 22 crops. Methodology for the definition of a key set of characterization and evaluation descriptors for sweet potato (Ipomoea batatas). Bioversity International, Rome, Italy. <https://www.bio versityinternational.org/fileadmin/_migrated/ uploads/tx_news/Key_characterization_and_ evaluation_descriptors_1440.pdf>.

Carey, D., B.E. Whipker, L.K. Bradley, and W.G. Buhler. 2012. Ornamental sweetpotatoes for the home landscape. AG 755, N. C. Coop. Ext. <https:// content.ces.ncsu.edu/static/publication/js/pdf_js/ $\mathrm{web} /$ viewer.html?slug=ornamental-sweetpotatoesfor-the-home-landscape>

Cavalcante, J.T., P.V. Ferreira, J.L.X.L. Cunha, L.L.M. Nobre, M.T. da Silva, D.S. Ferreira, A.B. Siva Júnior, and R.A. Paes. 2018. Interference of weeds in sweet potato genotype growth (Ipomoea batatas (L.) Lam.). Asian J. Adv. Res. Rpt. 1:1-11.

Chipungu, F., W. Changadeya, A. Ambali, J. Saka, N. Mahungu, and J. Mkumbira. 2017. Genetic and morphological diversity among sweet potato [Ipomoea batatas (L) Lam.] accessions from different geographical areas in Malawi. Afr. J. Biotechnol. 16:1285-1296.

CIP. 2010. Key access and utilization descriptors for sweet potato genetic resources. Biodiversity International, Rome (Italy); International Potato Centre (CIP), Lima, Peru, 11 p. <http:// hdl.handle.net/10568/73347>.

CIP. 2019. Cultivated sweetpotato germplasm collection. Genoveva Rossel, sweetpotato curator. International Potato Center (CIP), Lima, Peru. $<$ https://cipotato.org/genebankcip/process/ sweetpotato/sweet-cultivated $>$.

Cooper, L., A. Meier, M.-A. Laporte, J.L. Elser, C. Mungall, B.T. Sinn, D. Cavaliere, S. Carbon, N.A. Dunn, B. Smith, B. Qu, J. Preece, E. Zhang, S. Todorovic, G. Gkoutos, J.H. Doonan, D.W. Stevenson, E. Arnaud, and P. Jaiswal. 2018. The Planteome database: An integrated resource for reference ontologies, plant genomics and phenomics. Nucleic Acids Res. 46:D1168D1180.

Daros, M., A.T. Amaral, Jr., T.N.S. Pereira, N.R. Leal, S.P. Freitas, and T. Sediyama. 2002. Caracterização morfológica de acessos de batata-doce [Morphologic characterization of sweet potato]. Hort. Bras. 20:43-47.
Delazari, F.T., I.R. Assis, D.F.V. Cabrera, M.G. Ferreira, L.E. Dias, A. Rueda, J.C. Zanuncio, and D.J.H. Silva. 2018. Morpho-physiological characteristics by sweet potato cultivars as function of irrigation depth. An. Acad. Bras. Cienc. 90:3541-3549.

Dom, M.T., W.K. Ayalew, P.C. Glatz, R.N. Kirkwood, and P.E. Hughes. 2017. Nutrient utilisation in grower pigs fed a protein concentrate blended with sweet potato roots either boiled or ensiled with or without vines. Anim. Prod. Sci. 57:1645-1652.

Efisue, A.A. 2015. Genetic fingerprinting of sweet potato [Ipomoea batatas (L.) Lam] as revealed by isozyme electrophoresis analysis. Niger. J. Biotechnol. 30:36-47.

Elameen, A., S. Fjellheim, A. Larsen, O.A. Rognli, L. Sundheim, S. Msolla, E. Masumba, K. Mtunda, and S.S. Klemsdal. 2008. Analysis of genetic diversity in a sweet potato (Ipomoea batatas L.) germplasm collection from Tanzania as revealed by AFLP. Genet. Resources Crop Evol. 55:397-408.

Elameen, A., A. Larsen, S.S. Klemsdal, S. Fjellheim, L. Sundheim, S. Msolla, E. Masumba, and O.A. Rognli. 2011. Phenotypic diversity of plant morphological and root descriptor traits within a sweet potato, Ipomoea batatas (L.) Lam., germplasm collection from Tanzania. Genet. Resources Crop Evol. 58:397-407.

Fajardo, S., D.R. Labonte, and R.L. Jarret. 2002. Identifying and selecting for genetic diversity in Papua New Guinea sweetpotato Ipomoea batatas (L.) Lam. germplasm collected as botanical seed. Genet. Resources Crop Evol. 49:463-470.

FAO. 2010. The Second Report on the State of the World's Plant Genetic Resources for Food and Agriculture. Commission on Genetic Resources for Food and Agriculture, Food and Agriculture Organization (FAO) of the United Nations, Rome, Italy, 370 p. <http://www. fao.org/3/i1500e/i1500e.pdfs.

Fongod, A.G.N., A.M. Mih, and T.N. Nkwatoh. 2012. Morphological and agronomical characterization of different accessions of sweet potatoe (Ipomoea batatas) in Cameroon. Intl. Res. J. Agr. Sci. Soil Sci. 2:234-245. <https:// www.cabdirect.org/cabdirect/FullTextPDF/2012/ 20123357900.pdf $>$.

Galal, O.A. and A.S.A. El Gendy. 2017. Genetic characterization of three Egyptian sweet potato genotypes based on morpho-agronomic and molecular markers. Egypt. J. Genet. Cytol. 46:283-295.

Gichuki, S.T., M. Berenyi, D.P. Zhang, M. Hermann, J. Schmidt, J. Glossl, and K. Burg. 2003. Genetic diversity in sweetpotato [Ipomoea batatas (L.) Lam.] in relationship to geographic sources as assessed with RAPD markers. Genet. Resources Crop Evol. 50:429-437.

Glato, K., A. Aidam, N.A. Kane, D. Bassirou, M. Couderc, L. Zekraoui, N. Scarcelli, A. Barnaud, and Y. Vigouroux. 2017. Structure of sweet potato (Ipomoea batatas) diversity in West Africa covaries with a climatic gradient. PLoS One 12:e0177697.

Grüneberg, W.J., K. Manrique, D.-P. Zhang, and M. Hermann. 2005. Genotype x environment interactions for a diverse set of sweetpotato clones evaluated across varying ecogeographic conditions in Peru. Crop Sci. 45:2160-2171.

Grüneberg, W.J., D. Ma, R.O.M. Mwanga, E.E. Carey, K. Huamani, F. Diaz, R. Eyzaguirre, E. Guaf, M. Jusuf, A. Karuniawan, K. Tjintokohadi, Y.-S. Song, S.R. Anil, M. Hossain, E. Rahaman, S.I. Attaluri, S. Koussao, S.O. Afuape, K. Adofo, E. Lukonge, L. Karanja, J. Ndirigwe, G. Ssemakula,
S. Agili, J.M. Randrianaivoarivony, M. Chiona, F. Chipungu, S.M. Laurie, J. Ricardo, M. Andrade, F. Rausch Fernandes, A.S. Mello, M.A. Khan, D.R. Labonte, and G.C. Yencho. 2015. Advances in sweetpotato breeding from 1992 to 2012, p. 3-68. In: J. Low, M. Nyongesa, S. Quinn, and M. Parker (eds.). Potato and sweetpotato in Africa: Transforming the value chains for food and nutrition security. Ninth Triennial African Potato Association Conference, Naivasha, Kenya, 30 June-4 July 2013. CAB Internat., Oxfordshire, UK. <https://doi.org/10.1079/ 9781780644202.0003>.

Gupta, S., S. Pareek, K.D. Ameta, D.K. Sarolia, R.A. Kaushik, and H.K. Jain. 2018. Agronomic evaluation of sweet potato (Ipomoea batatas L.) germplasm. Intl. J. Curr. Microbiol. Appl. Sci. 7:738-742.

Gupta, S., D.M. Rosenthal, J.R. Stinchcombe, and R.S. Baucom. 2019. The remarkable morphological diversity of leaf shape in sweet potato (Ipomoea batatas): The influence of genetics, environment, and GxE. New Phytol. Available at: $<$ https://doi.org/10.1111/nph. 16286>.

Hao, Y.-M., L. Guo, Y.-C. Han, Y. Diao, X.-S. Yang, and Z.-L. Hu. 2007. Genetic diversity analysis of sweet potato based on SRAP makers. J. Wuhan Bot. Res. 25:406-409. http://en.cnki.com.cn/Article_en/CJFDTotalWZXY200704016.htm.

Harrison, H.F. and D.M. Jackson. 2011. Response of two sweetpotato cultivars to weed interference. Crop Prot. 30:1291-1296.

He, X.-Q., Q.-C. Liu, K. Ishiki, H. Zhai, and Y.-P. Wang. 2006. Genetic diversity and genetic relationships among Chinese sweetpotato landraces revealed by RAPD and AFLP markers. Breed. Sci. 56:201-207.

Hualla, V.R., R. Simon, R. Mwanga, H.S. Juarez Soto, and G. Rossel Montesinos. 2015. The sweetpotato ontology. Metadata and ubiquitous access to culture, p. 206-208. In: Proc. Intl Conf. Dublin Core Metadata Appl., 1-4 Sept. 2015, Sao Paulo, Brazil. <http://hdl.handle.net/ 10568/72497>.

Huamán, Z. 1988. Descriptors for the characterization and evaluation of sweetpotato genetic resources, p. 331-355. In: P. Gregory (ed.). Exploration, maintenance, and utilization of sweet potato genetic resources: Report of the first sweet potato planning conference 1987. Intl. Potato Ctr. (CIP), Lima, Peru.

Huamán, Z. 1991. Descriptors for sweet potato. Intl. Board Plant Genet. Resources, Rome, Italy, 134 p. <https://www.bioversityinternational.org/ fileadmin/_migrated/uploads/tx_news/Descriptors_ for_sweet_potato_Descripteurs_pour_la_patate_ douce_Descriptores_de_la_batata_263.pdf $>$.

Huamán, Z. 1992. Morphologic identification of duplicates in collections of Ipomoea batatas. CIP Res. Guide 36, Intl. Potato Ctr. (CIP), Lima, Peru.

Huamán, Z. and F. de la Puente. 1988. Development of a sweet potato genebank at CIP. Intl. Potato Ctr. (CIP). CIP Circ. 16:1-7.

Huang, J.C. and M. Sun. 2000. Genetic diversity and relationships of sweetpotato and its wild relatives in Ipomoea series batatas (Convolvulaceae) as revealed by inter-simple sequence repeat (ISSR) and restriction analysis of chloroplast DNA. Theor. Appl. Genet. 100:10501060.

Hue, S.M., S. Chandran, and A.N. Boyce. 2012 Variations of leaf and storage roots morphology in Ipomoea batatas L. (sweet potato) cultivars. Acta Hort. 943:73-80. 
Irwan, M., D.S. Hanafiah, N. Rahmawati, and D. Bakti. 2019. Analysis of changes in morphological characteristics of leaves and stems in some sweet potato cultivars (Ipomoea batatas L.) from Simalungun and Dairi highlands planting in the lowlands. IOP Conf. Ser.: Earth Environ. Sci., IOP Publ. Vol. 260, paper o12150. <https:// doi.org/10.1088/1755-1315/260/1/012150>.

Islam, M.S. 2006. Sweetpotato (Ipomoea batatas L.) leaf: Its potential effect on human health and nutrition. J. Food Sci. 71:R13-R21.

Jackson, D.M., H.F. Harrison, R.L. Jarret, and P.A. Wadl. 2018. Color analysis of storage roots from the USDA, ARS sweetpotato (Ipomoea batatas) germplasm collection. Genet. Resources Crop Evol. 65:1217-1236.

Jackson, D.M., H.F. Harrison, R.L. Jarret, and P.A. Wadl. 2019a. Phenotypic analysis of leaf colours from the USDA, ARS Sweetpotato (Ipomoea batatas) germplasm collection. Plant Genet. Resources 17, 14 p. <https://doi.org/10.1017/ s1479262119000042>

Jackson, D.M., H.F. Harrison, R.L. Jarret, and P.A. Wadl. 2019b. Data from: Phenotypic variation in leaf morphology of the USDA, ARS Sweetpotato (Ipomoea batatas) germplasm collection. Ag Data Commons Beta, U.S. Dept. Agr., Agr. Res. Serv., Nat. Agr. Lib. <https://data. nal.usda.gov/dataset/data-phenotypic-variation-leafmorphology-usda-ars-sweetpotato-germplasmcollection $>$.

Jandrew, J. 2008. Ipomoea plant named 'Seki Lim'. Syngenta Crop Protection AG, Basel, Switzerland. U.S. Plant Patent US PP20,616 P2. $<$ https://patentimages.storage.googleapis.com/ 56/50/72/d390093176bc99/USPP20616.pdf $>$.

Jandrew, J. 2010a. Ipomoea plant named 'Seki Blahrt'. Syngenta Crop Protection AG, Basel, Switzerland. U.S. Plant Patent US PP20,813 P2. $<$ https://patentimages.storage.googleapis.com/ 02/f8/d5/4be8896e1f666a/USPP20813.pdf>.

Jandrew, J. 2010b. Ipomoea plant named 'Seki Blapalm'. Syngenta Crop Protection AG, Basel, Switzerland. U.S. Plant Patent US PP20,880 P2. $<$ https://patentimages.storage.googleapis.com/ 7a/a6/7f/9919523e1d5059/USPP20880.pdf > .

Jarret, R.L. and D.F. Austin. 1994. Genetic diversity and systematic relationships in sweetpotato [Ipomoea batatas (L.) Lam.] and related species as revealed by RAPD analysis. Genet. Resources Crop Evol. 41:165-173.

Jarret, R.L., N.L. Anglin, D. Ellis, A. Villordon, P. Wadl, and M. Jackson. 2019. Sweetpotato genetic resources: Today and tomorrow. Burleigh Dodds Sci. Publ. Lim., Cambridge, UK, paper ID number 9781786764348, 52 p. <http:// dx.doi.org/10.19103/AS.2019.0016.18>.

Johnson, M. and R.D. Pace. 2010. Sweet potato leaves: Properties and synergistic interactions that promote health and prevent disease. Nutr. Rev. 68:604-615.

Kagimbo, F.M., H. Shimelis, and J. Sibiya. 2018. Diversity assessment of sweetpotato germplasm collections for yield and yield-related traits in western Tanzania. Acta Agr. Scand., Sect. B-Soil. Plant Sci. 68:121-129.

Karuri, H.W., E.M. Ateka, R. Amata, A.B. Nyende, A.W.T. Muigai, E. Mwasame, and S.T. Gichuki. 2010. Evaluating diversity among Kenyan sweet potato genotypes using morphological and SSR markers. Intl. J. Agr. Biol. 12:33-38. <https://pdfs. semanticscholar.org/2a19/5b755e074b33d70d 891d0e780de5404f3961.pdf>.

Khoury, C.K., B. Heider, N.P. Castañeda-Álvarez, H.A. Achicanoy, C.C. Sosa, R.E. Miller, R.W Scotland, J.R.I. Wood, G. Rossel, L.A. Eserman, R.L. Jarret, G.C. Yencho, V. Bernau, H. Juarez, S. Sotelo, S. de Haan, and P.C. Struik. 2015.
Distributions, ex situ conservation priorities, and genetic resource potential of crop wild relatives of sweetpotato [Ipomoea batatas (L.) Lam., I. series Batatas]. Front. Plant Sci. 6:251.

Kim, H.S., C.-J. Lee, S.-E. Kim, C.Y. Ji, S.-T. Kim, J.-S. Kim, S. Kim, and S.-S. Kwak. 2018 Current status on global sweetpotato cultivation and its prior tasks of mass production. J. Plant Biotechnol. 45:190-195.

Kim, J.-H., J.-H. Kim, W.-S. Jo, J.-G. Ham, I.K. Chung, and K.-M. Kim. 2016. Characterization and development of EST-SSR markers in sweet potato [Ipomoea batatas (L.) Lam]. 3 Biotech 6:243. <https://doi.org/10.1007/s13205-0160565-9>.

Korese, J.K. and O. Hensel. 2016. Resistance to airflow through sweet potato aerial vine components. Appl. Eng. Agr. 32:483-491.

Koussao, S., V. Gracen, I. Asante, E.Y. Danquah, J.T. Ouedraogo, T.J. Baptiste, and T.M. Vianney. 2014. Diversity analysis of sweet potato [Ipomoea batatas (L.) Lam] germplasm from Burkina Faso using morphological and simple sequence repeats markers. Afr. J. Biotechnol. 13:729-742.

Labonte, D.R., H.F. Harrison, and C.E. Motsenbocker. 1999. Sweetpotato clone tolerance to weed interference. HortScience 34:229-232.

Laurie, S.M. and M. Booyse. 2015. Employing GGE SREG model plus Elston index values for multiple trait selection in sweetpotato. Euphytica 204:433-442.

Loebenstein, G. and G. Thottappilly. 2009. The sweetpotato. Springer Sciences Business Media BV, Dordrecht, The Netherlands.

Luo, K., H.-X. Lu, Z.-D. Wu, X.-L. Wu, W. Yin, D.-B. Tang, J.-C. Wang, and K. Zhang. 2016. Genetic diversity and population structure analysis of main sweet potato breeding parents in Southwest China. Scientia Agricultura Sinica 49:593-608.

Luo, W.-B., N.-T. Cai, Y.-X. Qiu, Q.-Y. Wu, and Y.-G. Xu. 2008. Genetic diversity in sweet potato by ISSR markers. J. Northwest A\&F Univ. (Natural Sci. Ed.) 208:10. http://en.cnki. com.cn/Article_en/CJFDTotal-XBNY200810018.htm.

Manifesto, M.M., S.M. Costa Tártara, C.M. Arizio, M.A. Alvarez, and N.R. Hompanera. 2010. Analysis of the morphological attributes of a sweetpotato collection. Ann. Appl. Biol. 157:273-281.

Manrique, K. and M. Hermann. 2001. Effect of GxE interaction on root yield and beta-carotene content of selected sweetpotato [Ipomoea batatas (L) Lam.] varieties and breeding clones, p. 281-287. In: Scientist and farmer: Partners in research for the 21st century. Program Report 1999-2000, Intl. Potato Ctr. (CIP), Lima, Peru. <http://www.sweetpotatoknowledge.org/wp-content/uploads/2016/02/ Effect-of-GxE-Interaction-on-Root-Yield-andBetacarotene-Content-of-Selected-SweetpotatoVarieties-and-Breeding-Clones.pdf $>$.

Maquia, I., I. Muocha, A. Naico, N. Martins, M. Gouveia, I. Andrade, L.F. Goulao, and A.I. Ribeirod. 2013. Molecular, morphological and agronomic characterization of the sweet potato (Ipomoea batatas L.) germplasm collection from Mozambique: Genotype selection for drought prone regions. S. Afr. J. Bot. 88:142151.

Martin, F.W. 1984. Development and characteristics of twining sweet potatoes. Proceed. Carib. Food Crops Soc. 20:200-201. <https://agecon search.umn.edu/record/261594/>.

Meier, A., L. Cooper, J. Elser, P. Jaiswal, and M.-A. Laporte. 2016. Annotating germplasm to Planteome reference ontologies: A semiautomated methodology. ICBO/BioCreative.
$<$ https://pdfs.semanticscholar.org/1c 7 d/ 47db367fe1be82b9494e99674ecb8b541d54.pdf>.

Meng, Y.-S., N. Zhao, H. Li, S.-Z. He, and Q.-C. Liu. 2018. SSR fingerprinting of 203 sweetpotato (Ipomoea batatas (L.) Lam.) varieties. J. Integr. Agr. 17:86-93.

Meszaros, D. 2007. Ipomoea plant named 'IP059'. Advanced Plant Technologies, LLC. U. S. Plant Patent US PP18,301 P2. < https://patentimages. storage.googleapis.com/ed/9b/d4/1479cb795c9dd1/ USPP18301.pdf>.

Meyers, S.L., K.M. Jennings, J.R. Schultheis, and D.W. Monks. 2010. Interference of Palmer amaranth (Amaranthus palmeri) in sweetpotato. Weed Sci. 58:199-203.

Mohan, C., A.G. Nair, and S.K. Naskar. 2012. Molecular mapping and genetic diversity studies in sweet potato, p. 57-64. In: M. Nedunchezhiyan and G. Byju (eds). Sweet potato. Fruit, vegetable and cereal science and biotechnology, Vol. 6 (Spec. Issue 1). Global Sci. Books, Kagawa ken, Japan. <http://www. globalsciencebooks.info/Online/GSBOnline/ images/2012/FVCSB_6(SI1)/FVCSB_6(SI1) 57-64o.pdf $>$.

Moyer, J.W. and L.F. Salazar. 1989. Viruses and viruslike diseases of sweetpotato. Plant Dis. 73:451-455.

Murashige, T. and F. Skoog. 1962. A revised medium for rapid growth and bio assays with tobacco tissue culture. Physiol. Plant. 15:473497.

Murugan, S., S.K. Paramasivam, and M. Nedunchezhiyan. 2012. Sweet potato as an animal feed and fodder, p. 106-114. In: M. Nedunchezhiyan and G. Byju (eds.). Sweet potato. Fruit, vegetable and cereal science and biotechnology, Vol. 6 (Spec. Issue 1). Global Science Books, Kagawa ken, Japan. <http://www.globalsciencebooks.info/Online/GSBOnline/images/ 2012/FVCSB_6(SI1)/FVCSB_6(SI1)106114o.pdf>

Mwanga, R.O.M., M.I. Andrade, E.E. Carey, J.W Low, G.C. Yencho, and W.J. Grüneberg. 2017. Sweetpotato (Ipomoea batatas L.), p. 181-218. In: H. Campos and P.D.S. Caligari (eds.). Genetic improvement of tropical crops. Springer Intl. Publ., Basel, Switzerland.

Mwololo, J.K., P.W. Muturi, M.W.K. Mburu, R.W. Njeru, N. Kiarie, J.K. Munyua, E.M. Ateka, R.W. Muinga, R.E. Kapinga, and B. Lemaga. 2009. Additive main effects and multiplicative interaction analysis of genotype $\mathrm{x}$ environmental interaction among sweetpotato genotypes. J. Anim. Plant Sci. 2:148-155. <http://41.89.129.9/bitstream/ handle/123456789/629/Additive\%20main\% 20 effects $\% 20$ and $\% 20$ multiplicative.pdf? sequence $=1>$.

Neiva, I.P., V.C. Andradede de Júnior, D.J.S. Viana, J.A. Figueiredo, C.V. Mendonça Filo, R.A.C. Parrella, and J.B. Santos. 2011. Caracterização morfológica de acessos de batata-doce do banco de germoplasma da UFVJM. Diamantina. Hort. Bras. 29:537-541

Ngailo, S., H. Shimelis, J. Sibiya, B. Amelework, and K. Mtunda. 2016. Genetic diversity assessment of Tanzanian sweetpotato genotypes using simple sequence repeats. S. Afr. J. Bot. 102:40-45.

Ngailo, S., H. Shimelis, J. Sibiya, K. Mtunda, and J. Mashilo. 2019. Genotype-by-environment interaction of newly-developed sweet potato genotypes for storage root yield, yield-related traits and resistance to sweet potato virus disease. Heliyon 5; article no. e01448, 23 p. <https:// doi.org/10.1016/j.heliyon.2019.e01448>.

Nwankwo, I.I.M., E.E. Bassey, S.O. Afuape, J. Njoku, D.S. Korieocha, G. Nwaigwe, and 
T.N.C. Echendu. 2012. Morpho-agronomic characterization and evaluation of in-country sweet potato accessions in southeastern Nigeria. J. Agr. Sci. 4:281-288.

Ochieng, L.A. 2019. Agro-morphological characterization of sweet potato genotypes grown in different ecological zones in Kenya. J. Hort. Plant Res. 5:1-12.

Palumbo, G.N., A.C. Galvao, C. Nicoletto, P. Sambo, and G. Barcaccia. 2019. Diversity analysis of sweet potato genetic resources using morphological and qualitative traits and molecular markers. Genes 10:840.

Pecota, K., G.C. Yencho, and C. Pierce. 2004a. Ornamental sweetpotato plant named 'Sweet Caroline Purple'. U.S. Plant Patent No. US PP14,912 P3. <http://www.google.com/patents/ USPP14912>.

Pecota, K., G.C. Yencho, and C. Pierce. 2004b. Ornamental sweetpotato plant named 'Sweet Caroline Green'. U.S. Plant Patent No. US PP15,056 P2. <http://www.google.com/patents/ USPP15056>.

Pecota, K., G.C. Yencho, and C. Pierce. 2004c. Ornamental sweetpotato plant named 'Sweet Caroline Bronze'. U.S. Plant Patent No. US PP15,437 P3. <http://www.google.com/patents/ USPP15437>.

Pipan, B., D. Žnidarčič, N. Kunstelj, and V. Meglič. 2017. Genetic evaluation of sweetpotato accessions introduced to the central European area. J. Agr. Sci. Technol. 19:1139-1150. <https://jast. modares.ac.ir/article-23-3196-en.pdfs.

Placide, R., H. Shimelis, M. Laing, and D. Gahakwa. 2015. Phenotypic characterisation of sweetpotato genotypes grown in East and Central Africa. S. Afr. J. Plant Soil 32:77-86.

Rahajeng, W. and S.A. Rahayuningsih. 2017. Agronomic performance, variance component, and diversity of sixty-two sweet potato accessions. Biodiversitas 18:95-100.

Rahman, H., A.F.M. Saiful Islam, M.A. Maleque, and R. Tabassum. 2015. Morpho-physiological evaluation of sweet potato (Ipomoea batatas L.) genotypes in acidic soil. Asian J. Crop Sci. 7:267-276.

Reddy, R., H. Soibam, V.S. Ayam, P. Panja, and S. Mitra. 2018. Morphological characterization of sweet potato cultivars during growth, development and harvesting. Indian J. Agr. Res. 52:46-50.

Roca, W.M., G.R. Montesino, D. Campilan, B. Laliberté, D. Renoso, R. Rao, and H. de Chavez. 2007. Global strategy for ex-situ conservation of sweet potato genetic resources. Sweetpotato Genetic Resources ConservationCIP Genebank. CIP, Lima, Peru, 76 p. $<$ https:// www.croptrust.org/wp-content/uploads/2015/ 05/SweetPotato-Strategy-FINAL-12Dec07.pdf $>$.

Rodriguez-Bonilla, L., H.E. Cuevas, M. MonteroRojas, F. Bird-Pico, D. Luciano-Rosario, and D. Siritunga. 2014. Assessment of genetic diversity of sweet potato in Puerto Rico. PLoS One 9(12):E116184.

Rosero, A., J.-L. Pérez, D. Rosero, W. Burgos-Paz, R. Martínez, J. Morelo, I. Pastrana, E. Burbano, and A. Morales. 2019. Morphometric and colourimetric tools to dissect morphological diversity: An application in sweet potato [Ipomoea batatas (L.) Lam.]. Genet. Resources Crop Evol. 66:1257-1278.

Seem, J.E., N.G. Creamer, and D.W. Monks. 2003. Critical weed free period for 'Beauregard' sweetpotato (Ipomoea batatas). Weed Technol. 17:686-695.

Selaocoe, M.E., P. Adebola, M. Pillay, and S.M. Laurie. 2019. Genetic diversity of South African sweetpotato germplasm using molecular markers. J. Crop Improv. 33:814-833.
Semidey, N., L.C. Liu, and F.H. Ortiz. 1987. Competition of pigweed (Amaranth dubius) with sweetpotato (Ipomoea batatas). J. Agr. Univ. P. R. 71:7-11. <https://revistas.upr.edu/ index.php/jaupr/article/view/6919/5569>.

Shen, S., G. Xu, D.R. Clements, G. Jin, A. Chen, F. Zhang, and H. Kato-Noguchi. 2015. Suppression of the invasive plant mile-a-minute (Mikania micrantha) by local crop sweet potato (Ipomoea batatas) by means of higher growth rate and competition for soil nutrients. BMC Ecol. 15:1. <https://doi.org/10.1186/s12898014-0033-5>

Shen, S., G. Xu, D. Li, G. Jin, S. Liu, D.R. Clements, Y. Yang, J. Rao, A. Chen, F. Zhang, X. Zhu, and L.A. Weston. 2019. Potential use of sweet potato (Ipomoea batatas (L.) Lam.) to suppress three invasive plant species in agroecosystems (Ageratum conyzoides L., Bidens pilosa L., and Galinsoga parviflora Cav.). Agronomy 9:1-13.

Shumbusha, D., H. Shimelis, M. Laing, and T. Asiimwe. 2017. Phenotypic diversity analysis of sweetpotato for breeding dual-purpose varieties. Acta Agr. Scand. Sect. B 67:340-351.

da Silva, A.V.C., L.N.T. Andrade, A.R.C. Rabbani, M.U.C. Nunes, and L.R. Pinheiro. 2013. Genetic diversity of sweet potatoes collection from Northeastern Brazil. Afr. J. Biotechnol. 13:1109-1116.

Soegianto, A., N.R. Ardiarini, and A.N. Sugiharto. 2011. Genetic diversity of sweet potato (Ipomoea batatas L.) in East Java, Indonesia. J. Agr. Food Technol. 1:179-183. <https://www.researchgate. net/profile/Andy_Soegianto/publication/267752767_ Genetic_diversity_of_sweetpotato_in_East_Java_ Indonesia/links/5459b5480cf2bccc4912c585. pdf $>$.

Su, W., Y. Liu, J. Lei, L. Wang, S. Chai, C. Jiao, and X. Yang. 2016. Phenotypic variation analysis of sweet potato germplasm resources from different agro-climate zones in the world. Amer. J. Expt. Agr. 13:1-13.

Su, W., L. Wang, J. Lei, S. Chai, Y. Liu, Y. Yang, X. Yang, and C. Jiao. 2017. Genome-wide assessment of population structure and genetic diversity and development of a core germplasm set for sweet potato based on specific length amplified fragment (SLAF) sequencing. PLOS One 12:E0172066.

Sugiura, R. and T. Watanabe. 2011. Effect of airflow drying and steam blanching on polyphenol retention in sweet potato leaves. Trans. Amer. Soc. Agr. Biol. Eng. 54:563-569.

Sulistiani, R., L.A.M. Rosmayati, Siregar, and F. Harahap. 2018. Differences in morphology and sugar content of purple sweet potato (Ipomoea batatas L.) with potassium treatment at several altitudes. IOP Conf. Ser.: Earth Environ. Sci., IOP Publ. Vol. 122, paper no. 012050. <https:// doi.org/10.1088/1755-1315/122/1/012050>.

Sultan, S.E. 2000. Phenotypic plasticity for plant development, function and life history. Trends Plant Sci. 5:537-542.

Tairo, F., E. Mneney, and A. Kullaya. 2008. Morphological and agronomical characterization of sweet potato [Ipomoea batatas (L.) Lam.] germplasm collection from Tanzania. Afr. J. Plant Sci. 2:7785. <https://pdfs.semanticscholar.org/6c94/52f2c be222bab5aa6730b6c6169e630a7035.pdf>

Talmadge, P.A. 2011. Ipomoea plant named 'Fnpalblk'. Floranova Service Corp., Lompoc, CA. U. S. Plant Patent US PP21,726 P2. $<$ https://patentimages.storage.googleapis.com/ 8e/1e/bd/e8ad2f81cc215d/USPP21726.pdf>.

Tumwegamire, S., P.R. Rubaihayo, D.R. Labonte, F. Diaz, R. Kapinga, R.O.M. Mwanga, and W.J. Grüneberg. 2011. Genetic diversity in white- and orange-fleshed sweetpotato farmer varieties from east Africa evaluated by simple sequence repeat markers. Crop Sci. 51:11321142 .

USDA. 2007. Detailed soil maps, Charleston County, SC. Sheet Number 51. <http://soils. usda.gov/survey/online_surveys/south_carolina/ charleston/maps/charlestonmap51.pdf \$.

USDA. 2019a. Descriptors for sweetpotato. USDA, ARS, U.S. National Plant Germplasm System. <https://npgsweb.ars-grin. gov/gringlobal/descriptors.asp $x>$.

USDA. 2019b. Plant Genetic Resources Conservation Unit: Griffin, Georgia. United States Department of Agriculture, Agricultural Research Service. <https://www.ars.usda.gov/southeastarea/griffin-ga/pgrcu/>

USDA. 2019c. Sweetpotato. U.S. National Plant Germplasm System. <https://npgsweb.ars-grin. gov/gringlobal/crop.asp $x>$.

Veasey, E.A., J.R. de Queiroz-Silva, M.S. Rosa, A. Borges, E. de Andrade Bressan, and N. Peroni. 2007. Phenology and morphological diversity of sweet potato (Ipomoea batatas) landraces of the Vale do Ribeira. Sci. Agr. 64:416-427.

Veasey, E.A., A. Borges, M.S. Rosa, J.R. QueirozSilva, E. de Andrade Bressan, and N. Peroni. 2008. Genetic diversity in Brazilian sweet potato [Ipomoea batatas (L.) Lam.] landraces assessed with microsatellite markers. Genet. Mol. Biol. 31:725-733.

Vimala, B. and R.B. Nair. 1988. Segregation pattern of some morphological characters in hybrid progenies of sweet potato (Ipomoea batatas L.). J. Root Crops 14:63-66.

Vimala, B., S. Attaluri, H. Binu, and W.J. Grüneberg. 2012. Variation in morphological characters and storage root yield among exotic orange-fleshed sweet potato clones and their seedling populations. J. Root Crops 38:32-37. <https://cgspace.cgiar.org/bitstream/ handle $/ 10568 / 66551 / 76852$.pdf? sequence $=1>$.

Wadl, P.A., B.A. Olukolu, S.E. Branham, R.L. Jarret, G.C. Yencho, and D.M. Jackson. 2018. Genetic diversity and population structure of the USDA sweetpotato (Ipomoea batatas) germplasm collections using GBSpoly. Front. Plant Sci. 9:1166.

Walker, D.W., T.J. Hubbell, and J.E. Sedberry. 1989. Influence of decaying sweet potato crop residues on nutrient uptake of sweet potato plants. Agr. Ecosyst. Environ. 26:45-52.

Winslow, B.K. 2018. Ipomoea plant named 'Balsotowac'. U.S. Plant Patent US PP29,511 P2. $<$ http://www.freepatentsonline.com/PP29511.pdfs.

Woolfe, J.A. 1992. Sweet potato: an untapped food reserve. Cambridge Univ. Press, Cambridge, UK

Yada, B., P. Tukamuhabwa, A. Alajo, and R.O.M. Mwanga. 2010. Morphological characterization of Ugandan sweetpotato germplasm. Crop Sci. 50:2364-2371.

Yada, B., G. Brown-Guedira, A. Alajo, G.N. Ssemakula, E. Owusu-Mensah, E.E. Carey, R.O.M. Mwanga, and G.C. Yencho. 2017. Genetic analysis and association of simple sequence repeat markers with storage root yield, dry matter, starch and $\beta$-carotene content in sweetpotato. Breed. Sci. 67:140-150.

Yang, X.-S., W.-J. Su, L.-J. Wang, J. Lei, S.-S. Chai, and Q.-C. Liu. 2015. Molecular diversity and genetic structure of 380 sweetpotato accessions as revealed by SSR markers. J. Integr. Agr. 14:633-641.

Yencho, G.C. and K. Pecota. 2008. Ornamental sweetpotato plant named 'Sweet Caroline Bewitched Purple'. U.S. Plant Patent No. US PP18,574 P3. $<$ http://www.google.com/patents/USPP18574>

Yencho, G.C., K. Pecota, and C.N. Hancock, Jr. 2008. Ornamental sweetpotato plant named 
'Sweet Caroline Sweetheart Light Green'. U.S. Plant Patent No. US PP18,572 P3. <http:// www.google.com/patents/USPP18572>.

Zawedde, B.M., M. Ghislain, E. Magembe, G.B. Amaro, R. Grumet, and J. Hancock. 2015. Characterization of the genetic diversity of Uganda's sweet potato (Ipomoea batatas) germplasm using microsatellites markers. Genet. Resources Crop Evol. 62:501-513.

Zhang, D., J. Cervantes, Z. Huamán, E. Carey, and M. Ghislain. 2000. Assessing genetic diversity of sweet potato (Ipomoea batatas (L.) Lam.) cultivars from tropical America using AFLP. Genet. Resources Crop Evol. 47:659-665.
Zhang, K., Z.-D. Wu, Y.-H. Li, H. Zhang, L.-P. Wang, Q.-L. Zhou, D.-B. Tang, Y.-F. Fu, F.-F. He, Y.-C. Jiang, H. Yang, and J.-C. Wang. 2014. ISSR-based molecular characterization of an elite germplasm collection of sweet potato (Ipomoea batatas L.) in China. J. Integr. Agr. 13:2346-2361. 